\title{
Microbiological Fractionation of Sulphur Isotopes
}

\author{
By I. R. KAPLAN* aND S. C. RITTENBERG \\ Department of Bacteriology, University of Southern California, Los Angeles, \\ California, U.S.A.
}

(Received 7 May 1963)

\begin{abstract}
SUMMARY
A fractionation of sulphur isotopes was found in all metabolic processes investigated except those in which elemental sulphur was the starting substrate for growth of Thiobacillus concretivorus and Chromatium sp. and for reduction by Saccharomyces cerevisiae. Except for polythionates formed during sulphide oxidation by $T$. concretivorus or Chromatium sp., the products of metabolism were enriched in ${ }^{32} \mathrm{~S}$ relative to the starting substrates. The magnitudes of the enrichment differed for different processes and for the same overall process carried out by different organisms. The $\delta^{34} \mathrm{~S}$ values $(\%)$ ranged from -46.0 for sulphide from sulphate reduction by Desulfovibrio desulfuricans to $+19 \cdot 0$ for polythionate formed during growth on sulphide by $\boldsymbol{T}$. concretivorus. Fractionation during sulphate reduction was inversely proportional to rate of reduction when lactate and ethanol were electron donors and directly proportional with molecular hydrogen as the electron donor. Temperature and sulphate concentration, within the normal physiological ranges of these parameters, influenced fractionation only in so far as they influenced rate of reduction. However, anomalous fractionation effects were obtained at low temperatures and when a resting suspension reducing sulphite was subjected to changes in temperature. The data are discussed with reference to the mechanism(s) of fractionation.
\end{abstract}

\section{INTRODUCTION}

The ability of micro-organisms to enrich one isotope of sulphur in preference to others during metabolic function was first demonstrated by Thode, Kleerekoper \& McElcheran (1951). They found that the sulphide released during sulphate reduction by growing cells of Desulfovibrio desulfuricans was enriched in the lighter isotope of sulphur $\left.{ }^{32} \mathrm{~S}\right)$ by a factor of $10-12 \%$. Subsequent observations by Jones \& Starkey (1957) showed that the degree of fractionation could be increased to $27 \%$ by growing cultures at reduced temperature $\left(14-20^{\circ}\right)$ and high sulphate concentration. They suggested that temperature regulated the rate of reduction, thereby controlling the enrichment. Similar results were obtained by Kaplan, Rafter \& Hulston (1960), who also found that the rate of sulphate reduction was the most important parameter controlling enrichment, with sulphate concentration playing a minor role. The fractionation phenomenon was critically studied by Harrison \& Thode (1958) using resting suspensions of $D$. desulfuricans. Their results demonstrated that the degree of fractionation was inversely proportional to the rate of reduction (controlled by temperature and electron donor concentration) and was influenced by sulphate only at limiting concentrations. Apart from some

* Present address: Laboratory for Microbiological Chemistry, Hadassah Medical School, Hebrew University, Jerusalem, Israel. 
experiments by Kaplan et al. (1960) with steel wool, lactate served as the electron donor in all the studies cited above. Jones \& Starkey (1957), Kaplan \& Rafter (1958) and Kaplan et al. (1960) could not demonstrate significant isotope fractionation during sulphur oxidation to sulphate by thiobacilli. The oxidation of hydrogen sulphide, however, yielded elemental sulphur and sulphate enriched in ${ }^{32} \mathrm{~S}$ (Kaplan \& Rafter, 1958).

Although many attempts have been made to interpret processes in nature in terms of microbiological fractionation of sulphur isotopes (Thode, Macnamara \& Fleming, 1953; Feely \& Kulp, 1957; Jensen, 1958; Kaplan et al. 1960, and others), only one attempt has been made to explain the underlying physiological events (Harrison \& Thode, 1958). The present study had as its objectives a re-investigation of fractionation during sulphate reduction and an extension of our knowledge of this phenomenon to other important metabolic processes in the sulphur cycle. A brief report of the work has been made (Kaplan \& Rittenberg, 1962b).

\section{METHODS \\ Microbiological}

Organisms and growth procedures. Desulfovibrio desulfuricans, Hildenborough strain, was used for most sulphate reduction studies. A few experiments, specifically mentioned in the text, were done with a second strain isolated in the authors' laboratory. Resting suspensions were prepared from cultures grown at $30^{\circ}$ in 12 l. flasks, using the mineral salts solution of Mechalas \& Rittenberg (1960) to which yeast extract $(1.0 \mathrm{~g} . / 1$.$) and sodium lactate (3.5 \mathrm{~g} . / \mathrm{l}$.$) were added. The yeast$ extract was omitted from the medium when fractionation measurements were made on growing cultures so that the added sulphate was the only sulphur source.

Thiobacillus concretivorus (Parker, 1947): isotope fractionation measurements were made with growing cultures oxidizing elemental sulphur or sulphide. In both instances, the base salts solution used contained (g./l. distilled $\mathbf{H}_{2} \mathrm{O}$ ): $\mathbf{K H}_{\mathbf{2}} \mathbf{P O}_{4}$, $3.0 ; \mathrm{MgCl}_{2}, 0 \cdot 1 ; \mathrm{CaCl}_{2}, 0 \cdot 1 ; \mathrm{NH}_{4} \mathrm{Cl}, 0 \cdot 2 ; \mathrm{pH} 4.6$. About $50 \mathrm{ml}$. of this solution plus $300 \mathrm{mg}$. elemental sulphur in $250 \mathrm{ml}$. Erlenmeyer flasks were used for sulphur oxidation studies. The sulphur was sterilized separately by heating on a steam bath on 3 consecutive days for $1 \mathrm{hr}$ each time. For growth on hydrogen sulphide, either several small flasks of the basal salts solution were incubated in a 201. container continually flushed with a mixture of $\mathrm{H}_{2} \mathrm{~S}+$ air $(3+3000 \mathrm{ml} . / \mathrm{hr})$, or the gas mixture was blown directly over thin layers of medium in Fernbach flasks.

Chromatium sp.: photosynthetic sulphide and sulphur oxidation were studied. The base medium contained (g./l. distilled $\mathrm{H}_{2} \mathrm{O}$ ): $\mathrm{KH}_{2} \mathrm{PO}_{4}, 1 \cdot 0 ; \mathrm{NH}_{4} \mathrm{Cl}, 1 \cdot 0 ; \mathrm{MgCl}_{2}$, 0.5 ; $\mathrm{NaCl}, 10$; trace elements (with no sulphate anions) in the concentrations suggested by Larsen (1953). To this was added $20 \mathrm{ml}$. of $10 \%$ (w/v) $\mathrm{NaHCO}_{3}$ separately autoclaved, cooled and aseptically saturated with $\mathrm{CO}_{2}$; also either $15 \mathrm{ml} .10 \%(\mathrm{w} / \mathrm{v})$ $\mathrm{Na}_{2} \mathrm{~S} .9 \mathrm{H}_{2} \mathrm{O}$ or $250 \mathrm{mg}$. sulphur, separately autoclaved. The $\mathrm{pH}$ was adjusted to $8 \cdot 2-8 \cdot 4$. The cultures were grown at $30^{\circ}$ in $500 \mathrm{ml}$. glass-stoppered bottles illuminated by tungsten filament lamps.

Saccharomyces cerevisiae was used to investigate fractionation while incorporating sulphate into organic sulphur during growth and also to study sulphite and elemental sulphur reduction by resting organisms. For the former purpose, yeasts were 
harvested for analysis after 2 days growth at $30^{\circ}$ on the following medium (g./l. distilled $\mathrm{H}_{2} \mathrm{O}$ ): glucose, 20.0; $\mathrm{KH}_{2} \mathrm{PO}_{4}, 1.0 ; \mathrm{NH}_{4} \mathrm{Cl}, 2 \cdot 0$; yeast extract, $0.5 ; \mathrm{Na}_{2} \mathrm{SO}_{4}$, $8.5 ; \mathrm{CaCl}_{2} .6 \mathrm{H}_{2} \mathrm{O}, 0.5 ; \mathrm{MgCl}_{2}, 0.5 ; \mathrm{FeCl}_{3}, 0.02$. For the latter experiments resting suspensions were prepared from commercially grown, starch-free cakes of Fleishmann's baker's yeast.

Ankistrodesmus sp. was grown on a modification of Knops medium (Curtis \& Clark, 1950, p. 384) having a total sulphur content (as $\mathrm{Na}_{2} \mathrm{SO}_{4}$ ) of $55 \mathrm{mg}$./l. The cultures were harvested after incubation at $30^{\circ}$ for 8 days and the isotopic composition of the organic sulphur determined.

Escherichia coli was grown on the medium suggested by Roberts et al. (1955, p. 5) having a sulphur content (as $\mathrm{Na}_{2} \mathrm{SO}_{4}$ ) of $500 \mathrm{mg}$./l. Bacteria were harvested after $40 \mathrm{hr}$ incubation at $30^{\circ}$ and the organic sulphur analysed.

Proteus vulgaris was grown in a $3 \%(\mathrm{w} / \mathrm{v})$ trypticase soy broth (Baltimore Biological Laboratories) with vigorous aeration. Cultures were harvested after $36 \mathrm{hr}$ at $30^{\circ}$ and used for resting suspension studies of cysteine degradation.

Resting suspension experiments. Desulfovibrio desulfuricans was separated from cultures by continuous centrifugation, rapidly washed twice with $0.01 \mathrm{M}$-potassium phosphate buffer ( $\mathrm{pH} \mathrm{7 \cdot 2)}$ suspended in deoxygenated buffer, and adjusted to the desired optical density. Known volumes of suspension were added to three-neck Woulfe bottles each fitted with a gas inlet and exit tube and a dropping funnel. The desired quantities of standard sodium sulphate or sulphite solution and, usually, sodium lactate or ethanol were then added, and the flasks incubated at controlled temperatures with constant flushing by a stream of deoxygenated nitrogen. When molecular hydrogen was used as the electron donor, it replaced nitrogen gas as the flushing agent.

A similar procedure was used for resting suspension studies with Saccharomyces cerevisiae and Proteus vulgaris. The yeasts were suspended in a potassium phosphate buffered $4 \%(\mathrm{w} / \mathrm{v})$ glucose solution at $\mathrm{pH} 5.5$; the bacteria were suspended in phosphate buffer ( $\mathrm{pH} \mathrm{7 \cdot 2)}$ containing $350 \mathrm{mg}$. cysteine hydrochloride/100 ml.

Optical density of suspensions. All resting suspension studies with Desulfovibrio desulfuricans were made at an optical density of 400 Klett-Summerson units (No. 54 filter) which corresponded to a direct microscopic count of $3.0 \times 10^{9}$ organisms/ml. Harrison \& Thode (1958) expressed their results in terms of a population equal to $100 \mathrm{ml}$. suspension of 0.1 optical density which is equivalent to $3 \times 10^{8}$ organisms $/ \mathrm{ml}$. The Proteus vulgaris suspensions had an optical density of $475 \mathrm{Klett}-$ Summerson units (No. 54 filter). The population of this suspension was not determined. Saccharomyces cerevisiae suspensions contained 2.5 g. yeast cake/100 ml., equivalent to $4 \times 10^{8}$ cells $/ \mathrm{ml}$.

\section{Chemical}

Collection of metabolites. Hydrogen sulphide. During sulphate, sulphite and elemental sulphur reduction, as well as cysteine hydrolysis, hydrogen sulphide is the end product. In the experiments using lactate, ethanol or glucose as electron donors, and in the experiments with cysteine, the sulphide released was removed by a stream of deoxygenated nitrogen and trapped in two consecutive chambers containing $\mathrm{AgNO}_{3}$. When hydrogen was employed, both as an electron donor and to sweep out $\mathrm{H}_{2} \mathrm{~S}, \mathrm{AgNO}_{3}$ could not be used because of the deposition of metallic silver, and $\mathrm{Cd}$ acetate was substituted. 
To determine the rate of sulphate reduction, sequential analyses were made of individual reaction vessels by periodically removing and assaying the precipitated sulphide in the traps. Some sulphide remains in the reaction vessel with this technique, and since there could be an isotope effect in the distribution of sulphide between the liquid and gaseous phases, this procedure was not followed when isotopic analyses were made. Instead, a single determination was made from each reaction vessel.

The fractionation experiments were designed to permit utilization of less than $5 \%$ of the added sulphur source. The quantity of precipitant required to bind the desired amount of sulphide was placed in the first trap with an equal quantity in the second. When precipitation was first observed in the second trap the microbial process was stopped by adding sufficient hydrochloric acid to make the culture about $\mathrm{pH} 2$ in experiments concerned with sulphate or sulphur reduction or cysteine decomposition. With sulphite, the $\mathrm{pH}$ value was adjusted to about 5 , since at low $\mathrm{pH}$ values $\mathrm{SO}_{2}$ is liberated which reacts with sulphide. After acidification, the vessels were placed in a hot water bath and bubbling was continued for about $15 \mathrm{~min}$. to ensure complete liberation of sulphide from solution.

Elemental sulphur, sulphate and polythionates. When formed, these were successively determined, after freeing the cultures of sulphide as above. The sulphur was collected by filtration through sintered glass; the sulphate was precipitated from the boiling filtrate as the barium salt; and the polythionates remaining were then oxidized with bromine and collected as barium sulphate.

Organic sulphur. Sulphur assimilated by organisms grown with sulphate as the sulphur source was converted to sulphate by wet combustion of the harvested cells and determined as the barium salt (Kaplan, 1962).

Preparation of samples for isotope measurements. Detailed descriptions of the methods have appeared elsewhere (Thode, Wanless \& Wallouch, 1954; Thode, Monster \& Dunford, 1961; Feely \& Kulp, 1957; Rafter, 1957; Hulston \& Shilton, 1958). The procedures followed in the present work were modifications of those described by Rafter and by Hulston \& Shilton (Kaplan, 1962).

Mass spectrometer analyses were made on sulphur dioxide prepared by combustion of silver sulphide or elemental sulphur in the presence of oxygen. All sulphate samples were first converted to sulphide by reduction with spectrographically pure graphite and reacted with silver nitrate to form silver sulphide. Elemental sulphur was burnt at $800^{\circ}$, while silver sulphide combustion was initiated at $600^{\circ}$ with rapid increase in temperature to $1200^{\circ}$.

Half the mass spectrometer analyses were made at the Institute of Nuclear Science, Lower Hutt, New Zealand, the rest at the University of California, La Jolla. Both instruments used are Nier $60^{\circ}$ sector types with double collection tubes and rapid sample switching devices. The instrumental error amounted to a standard deviation in $\delta^{34} \mathrm{~S}$ of $\mathbf{0} \cdot \mathbf{1 - 0}-\mathbf{2} \%$.

By convention, enrichment or depletion of ${ }^{34} \mathrm{~S}$ is expressed relative to a standard as $\delta$ values defined as follows:

$$
\delta^{34} \mathrm{~S} \%=\frac{\left({ }^{34} \mathrm{~S} /{ }^{32} \mathrm{~S}\right) \text { sample }-\left({ }^{34} \mathrm{~S} /{ }^{32} \mathrm{~S}\right) \text { standard }}{\left({ }^{34} \mathrm{~S} /{ }^{32} \mathrm{~S}\right) \text { standard }} \times 1000 .
$$

All $\delta^{34} \mathrm{~S}$ values are given relative to the starting substrate as the standard. 


\section{RESULTS}

\section{Sulphate reduction by Desulfovibrio desulfuricans}

Since previous investigators had established that fractionation is related to the rate of sulphate reduction, it was necessary to determine whether the metabolism of resting suspensions would be constant under the experimental conditions to be imposed and also to determine the effect of certain parameters on the rate of reduction. In general, sulphide production was linear over the time intervals investigated (Fig. 1). Sulphate concentration had little effect on the rate over the range of $0.02-0.06 \mathrm{M}$ but was inhibitory at $0.15 \mathrm{M}$. The electron donor markedly influenced rate of reduction. Molecular hydrogen, whose utilization followed a short lag period, gave the fastest rate. The rate with lactate was generally about one-half and that with ethanol about one-tenth the hydrogen rate.

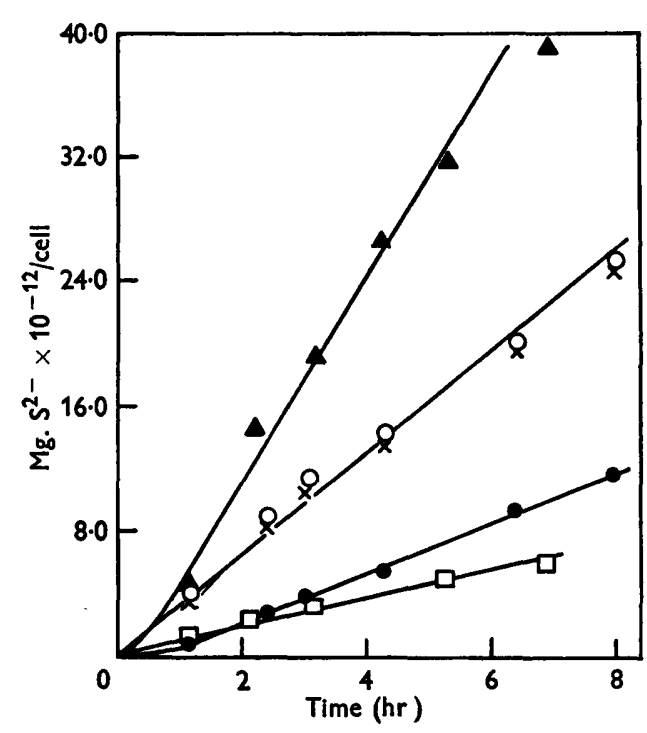

Fig. 1

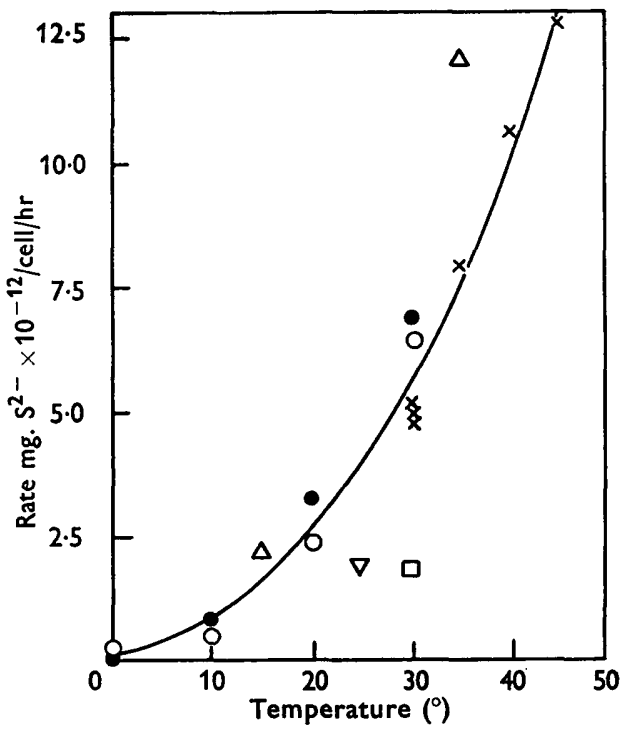

Fig. 2

Fig. 1. Rate of sulphate reduction by resting suspensions of Desulfovibrio desulfuricans

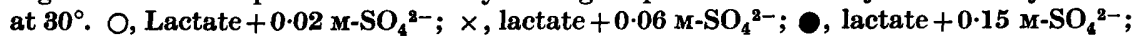

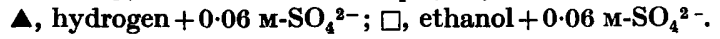

Fig. 2. Rate of sulphate reduction by resting suspensions of Desulfovibrio desulfuricans as a function of temperature; lactate as electron donor, 0.06 M-sulphate. Each symbol denotes a separate experiment conducted with a single batch of organisms.

The reduction process had a $Q_{10}$ of about 2 over a temperature range of $10-40^{\circ}$. A plot of rate against temperature for all resting suspension experiments using lactate and $0.06 \mathrm{M}$ sulphate (Fig. 2) shows a $\mathrm{d} R / \mathrm{d} T$ of about $5 \times 10^{-12} \mathrm{mg}$. sulphide/ organism/hr.

Effect of rate of reduction on isotope fractionation. The rate of reduction in individual experiments was altered by choice of temperature and hydrogen donor and was influenced by uncontrolled variations in different batches of resting organisms. Table 1 presents the rate and fractionation data obtained with three hydrogen 
donors and 0.06 $\mathrm{M}$-sulphate over a temperature range of $10-45^{\circ}$. Considering only lactate and ethanol, the best fit curve through the data is hyperbolic (Fig. 3) indicating that, with exceptions to be mentioned later, for these two hydrogen donors the isotope effect is inversely proportional to the rate of reduction, with the lighter

\section{Table 1. Isotopic fractionation during sulphate reduction by resting suspensions} of Desulfovibrio desulfuricans

Each experiment involved a different lot of organisms using $0.06 \mathrm{~m}$-sulphate and lactate, ethanol or hydrogen at the temperatures indicated. $\delta^{34} \mathrm{~S}$ measured relative to the ${ }^{34} \mathrm{~S} /{ }^{32} \mathrm{~S}$ of the starting sulphate. Expts. 1-5 with strain 'Hildenborough'; 6-8 with strain ' 2 '.

\begin{tabular}{|c|c|c|c|c|c|}
\hline $\begin{array}{c}\text { Expt. } \\
\text { No. }\end{array}$ & $\underset{\left({ }^{\circ}\right)}{\text { Temp. }}$ & $\begin{array}{c}\text { Electron } \\
\text { donor }\end{array}$ & $\begin{array}{c}\text { Sulphate } \\
\text { reduced } \\
(\%)\end{array}$ & $\begin{array}{c}\text { Rate of } \\
\text { reduction, } \\
\text { mg. } S^{2-} \times \\
10^{-12} / \\
\text { organism/ } \\
\mathrm{hr}\end{array}$ & $\begin{array}{c}\delta^{34} \mathrm{~S} \text { of } \mathrm{S}^{2-} \\
(\% 0)\end{array}$ \\
\hline 1 & $\begin{array}{r}30 \\
\mathbf{3 0} \\
\mathbf{3 0} \\
\mathbf{2 0} \\
\mathbf{1 0} \\
\mathbf{0}\end{array}$ & $\begin{array}{l}\text { Ethanol } \\
\mathrm{H}_{2} \\
\text { Lactate } \\
\text { Lactate } \\
\text { Lactate } \\
\text { Lactate }\end{array}$ & $\begin{array}{l}2 \cdot 61 \\
2 \cdot 17 \\
3 \cdot 04 \\
2 \cdot 37 \\
2 \cdot 31 \\
1 \cdot 19\end{array}$ & $\begin{array}{l}2 \cdot 17 \\
7 \cdot 18 \\
6 \cdot 48 \\
1 \cdot 85 \\
0 \cdot 50 \\
0 \cdot 13\end{array}$ & $\begin{array}{l}-26 \cdot 0 \\
-10 \cdot 8 \\
-25 \cdot 5 \\
-30 \cdot 3 \\
-35 \cdot 5 \\
-18 \cdot 6\end{array}$ \\
\hline 2 & $\begin{array}{r}30 \\
30 \\
30 \\
20 \\
10 \\
0\end{array}$ & $\begin{array}{l}\text { Ethanol } \\
\mathbf{H}_{2} \\
\text { Lactate } \\
\text { Lactate } \\
\text { Lactate } \\
\text { Lactate }\end{array}$ & $\begin{array}{l}\mathbf{2 \cdot 6 8} \\
\mathbf{3} \cdot 19 \\
\mathbf{2} \cdot 24 \\
\mathbf{2 \cdot 2 4} \\
\mathbf{2 \cdot 5 5} \\
\mathbf{0} \cdot \mathbf{8 5}\end{array}$ & \begin{tabular}{r|}
$5 \cdot 06$ \\
$14 \cdot 05$ \\
$6 \cdot 85$ \\
$2 \cdot 52$ \\
$0 \cdot 75$ \\
$0 \cdot 08$
\end{tabular} & $\begin{array}{r}-17 \cdot 1 \\
-10 \cdot 1 \\
-14 \cdot 8 \\
-15 \cdot 1 \\
-10 \cdot 0 \\
-5 \cdot 2\end{array}$ \\
\hline 3 & $\begin{array}{l}30 \\
20 \\
30 \\
10\end{array}$ & $\begin{array}{l}\text { Ethanol } \\
\text { Ethanol } \\
\mathbf{H}_{2} \\
\mathbf{H}_{2}\end{array}$ & $\begin{array}{l}2 \cdot 44 \\
2 \cdot 10 \\
2 \cdot 20 \\
2 \cdot 20\end{array}$ & $\begin{array}{l}0 \cdot 41 \\
0 \cdot 17 \\
2 \cdot 64 \\
0 \cdot 52\end{array}$ & $\begin{array}{r}-42 \cdot 3 \\
-44 \cdot 0 \\
-8 \cdot 4 \\
-3 \cdot 0\end{array}$ \\
\hline 4 & $\begin{array}{l}30 \\
20 \\
30 \\
20 \\
10\end{array}$ & $\begin{array}{l}\text { Ethanol } \\
\text { Ethanol } \\
\mathbf{H}_{2} \\
\mathbf{H}_{2} \\
\mathbf{H}_{2}\end{array}$ & $\begin{array}{l}\mathbf{2} \cdot 00 \\
\mathbf{2} \cdot 00 \\
\mathbf{2} \cdot 55 \\
\mathbf{3} \cdot 39 \\
\mathbf{2} \cdot 19\end{array}$ & $\begin{array}{r}0 \cdot 43 \\
0 \cdot 20 \\
12 \cdot 10 \\
7 \cdot 65 \\
1 \cdot 60\end{array}$ & $\begin{array}{r}-34 \cdot 9 \\
-46 \cdot 0 \\
-11 \cdot 2 \\
-6 \cdot 4 \\
-5 \cdot 0\end{array}$ \\
\hline 5 & $\begin{array}{l}45 \\
40 \\
35 \\
30 \\
30 \\
30 \\
30 \\
20\end{array}$ & $\begin{array}{l}\text { Lactate } \\
\text { Lactate } \\
\text { Lactate } \\
\text { Lactate } \\
\text { Lactate } \\
\text { Lactate } \\
\mathbf{H}_{2} \\
\mathbf{H}_{2}\end{array}$ & $\begin{array}{l}\mathbf{2} \cdot 70 \\
\mathbf{2} \cdot 95 \\
\mathbf{3} \cdot 01 \\
\mathbf{2} \cdot 64 \\
\mathbf{2 \cdot 6 7} \\
\mathbf{2} \cdot 7 \mathbf{7} \\
\mathbf{2} \cdot 40 \\
\mathbf{3} \cdot 03\end{array}$ & $\begin{array}{r}12 \cdot 80 \\
10 \cdot 80 \\
7 \cdot 95 \\
4 \cdot 85 \\
4 \cdot 90 \\
5 \cdot 10 \\
3 \cdot 85 \\
4 \cdot 20\end{array}$ & $\begin{array}{r}-16 \cdot 1 \\
-17 \cdot 3 \\
-19 \cdot 3 \\
-21 \cdot 4 \\
-20 \cdot 4 \\
-20 \cdot 9 \\
-8 \cdot 9 \\
-6 \cdot 3\end{array}$ \\
\hline 6 & $\begin{array}{l}30 \\
30 \\
20 \\
10\end{array}$ & $\begin{array}{l}\text { Lactate } \\
\mathbf{H}_{2} \\
\mathbf{H}_{2} \\
\mathbf{H}_{2}\end{array}$ & \begin{tabular}{|l|}
$\mathbf{3} \cdot 30$ \\
$\mathbf{3} \cdot 4 \mathbf{3}$ \\
$\mathbf{2} \cdot 63$ \\
$\mathbf{2} \cdot 21$
\end{tabular} & $\begin{array}{r}1 \cdot 74 \\
13 \cdot 30 \\
4 \cdot 70 \\
1 \cdot 12\end{array}$ & $\begin{array}{r}-18 \cdot 3 \\
-16 \cdot 5 \\
-14 \cdot 3 \\
-13 \cdot 8\end{array}$ \\
\hline 7 & $\begin{array}{r}25 \\
25 \\
15 \\
5\end{array}$ & $\begin{array}{l}\text { Lactate } \\
\mathbf{H}_{2} \\
\mathbf{H}_{2} \\
\mathbf{H}_{2}\end{array}$ & \begin{tabular}{|l|}
$\mathbf{3} \cdot 06$ \\
$3 \cdot 01$ \\
$\mathbf{3} \cdot 14$ \\
$0 \cdot 91$
\end{tabular} & $\begin{array}{l}1 \cdot 87 \\
7 \cdot 25 \\
2 \cdot 05 \\
0 \cdot 14\end{array}$ & $\begin{array}{l}-16 \cdot 3 \\
-13 \cdot 6 \\
-12 \cdot 9 \\
-14 \cdot 4\end{array}$ \\
\hline 8 & $\begin{array}{l}35 \\
15\end{array}$ & $\begin{array}{l}\text { Lactate } \\
\text { Lactate }\end{array}$ & $\begin{array}{l}1 \cdot 43 \\
1 \cdot 40\end{array}$ & $\begin{array}{r}12 \cdot 30 \\
2 \cdot 42\end{array}$ & $\begin{array}{l}-15 \cdot 5 \\
-16 \cdot 6\end{array}$ \\
\hline
\end{tabular}


isotope always being enriched in the sulphide produced. The shape of the curve is similar to that obtained by Harrison \& Thode (1958). Of particular interest is that several enrichments of ${ }^{32} \mathrm{~S}$ greater than $30 \%$ were measured, with the maximum reaching $46 \%$. The maximum reported in previous laboratory experiments (Jones \& Starkey, 1957; Harrison \& Thode, 1958) was $27 \%$, yet considerably higher enrichments are found in nature (Kaplan et al. 1960; Kaplan, Emery \& Rittenberg, 1963).

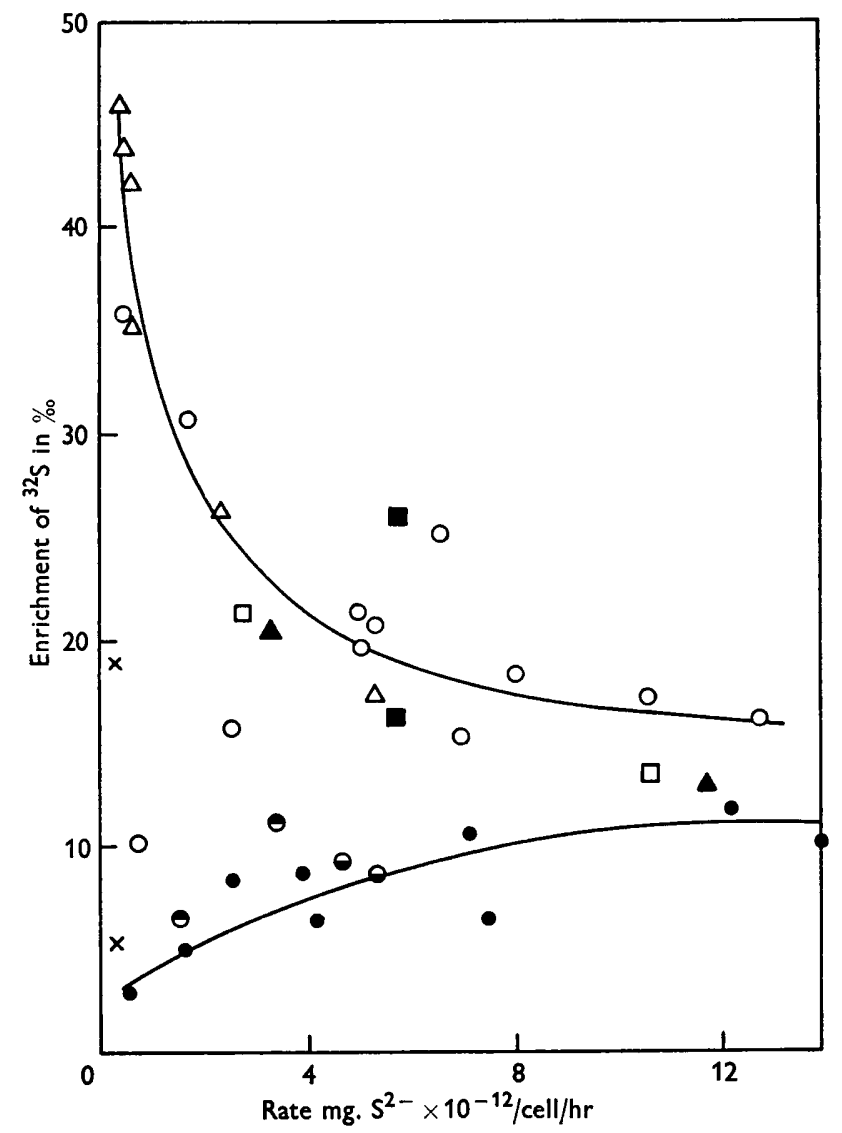

Fig. 8. Enrichment of ${ }^{32} \mathrm{~S}$ in hydrogen sulphide as a function of rate of sulphate reduction by Desulfovibrio desulfuricans. Temperature $10-45^{\circ}, 0.06{\mathrm{M}-\mathrm{SO}_{4}}^{2-}$; and lactate, $\mathrm{O}$;

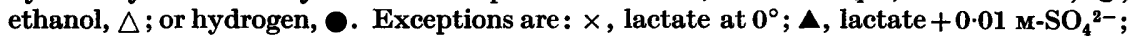

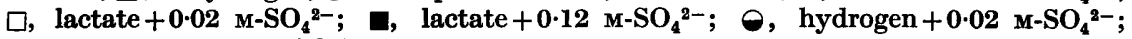

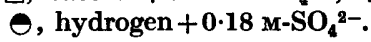

Effect of electron donor. Although at a particular temperature rates of reduction with ethanol were lower than those with lactate (Fig. 1), over the temperature range tested there was an overlapping of rates (Table 1). Since the fractionations obtained with both lactate and ethanol fall on the same curve when plotted against rate (Fig. 3), it is probable that these two electron donors influence fractionation only insofar as they influence rate of reduction.

However, isotope fractionation was always lower with molecular hydrogen as the electron donor than with the other donors at a comparable rate of reduction. In 
addition, isotope fractionation with hydrogen is directly related to rate, rather than inversely as with lactate and ethanol (Fig. 3). It is obvious that with molecular hydrogen the mechanism controlling isotope fractionation must be different.

Effect of temperature. Fractionation decreased with increasing temperature when ethanol (Expts. 3 and 4, Table 1) or lactate (Expts. 1 and 5, Table 1) was electron donor and increased with increasing temperature with molecular hydrogen (Expts. 3-5, Table 1). With the same donor and temperature, rates of reduction and fractionation differed with different batches of bacteria (Table 1). Thus over the range of $10-45^{\circ}$, temperature per se appears to influence isotope selection only through its influence on rate of sulphate reduction.

Some experiments were run with lactate at $0-10^{\circ}$. Sulphide production was very slow and appeared to diminish in rate over the long incubation period required to collect the necessary amount of sulphide for analysis. In these experiments $(x$, Fig. 3) the enrichments observed fell far below the normal lactate-ethanol curve. It is apparent that the usual mechanism controlling fractionation no longer functioned at the low temperatures imposed.

Effect of sulphate concentration. Several experiments were performed with lactate and hydrogen in which the sulphate concentration was varied over the range of $0 \cdot 01-0 \cdot 18 \mathrm{M}$. The enrichments show about the same relation to rate of reduction as those obtained with $0.06 \mathrm{M}$-sulphate (Fig. 3). Thus no independent sulphate concentration effect on fractionation over the range studied is suggested.

Strain variation. A few experiments were done with a second strain of Desulfovibrio desulfuricans, and the data are included in Table 1 . The enrichment patterns observed were similar, i.e. increasing fractionation with decreasing rate with lactate as the hydrogen donor and the reverse effect with molecular hydrogen. However, the magnitude of enrichment was higher with molecular hydrogen and lower with lactate as compared to the first strain, and the range, 12-19\%, was smaller.

Fractionation by growing cells of Desulfovibrio desulfuricans. Cultures were grown at $30^{\circ}$ using 0.02, 0.04, and $0.06 \mathrm{M}$-lactate, and $0.06 \mathrm{M}-\mathrm{SO}_{4}{ }^{2-}$. Experiments were terminated when $3 \cdot 32,5 \cdot 05$ and $8 \cdot 96 \%$ respectively of the sulphate had been reduced. The corresponding $\delta^{34} \mathrm{~S}$ values of the sulphide formed were $-12.9,-11 \cdot 2$, and $-12 \cdot 8 \%$ with respect to the starting sulphate. The fractionations were lower than those obtained with resting cells using the same electron donor and temperature (Table 1). Previous data (Jones \& Starkey, 1957; Harrison \& Thode, 1958; Kaplan et al. 1960) also show lower fractionations with growing cultures than those reported here for resting suspensions. Although this might suggest a different control mechanism for fractionation under the two physiological conditions, it must be emphasized that comparisons would only be valid on a rate of reduction per cell basis. Although this absolute rate was not determined for the exponentially growing cultures, experimental conditions were optimum, and a rapid rate of sulphide production per organism and a low fractionation would be expected. Such results were obtained by Harrison \& Thode (1958) whose data for resting and growing cells, expressed in terms of unit cell populations, fall on the same fractionation-rate curve. 


\section{Sulphite reduction by resting Desulfovibrio desulfuricans}

Under comparable conditions of concentration, temperature and electron donor, sulphite was reduced more rapidly than sulphate (cf. Postgate, 1951). The enrichment factor was always smaller than that during sulphate reduction (Table 2). With the exception of an experiment at $5^{\circ}$, in which rate of reduction was very slow and enrichment relatively high, there was no marked change in enrichment with reduction rate. These findings differ from those of Harrison \& Thode (1958) who found that both the rate of reduction and the fractionation were the same at equal sulphite and sulphate concentrations.

Table 2. Isotopic fractionation during sulphate and sulphite reduction by resting suspensions of Desulfovibrio desulfuricans, strain 2

Lactate as electron donor; $0.06 \mathrm{M}$-sulphate or sulphite. $\delta^{84} \mathrm{~S}$ measured relative to ${ }^{3} \mathrm{~S} /{ }^{32} \mathrm{~S}$ of starting sulphate or sulphite.

\begin{tabular}{|c|c|c|c|c|c|}
\hline $\begin{array}{c}\text { Expt. } \\
\text { no. }\end{array}$ & $\begin{array}{c}\text { Temp. } \\
\left({ }^{\circ}\right)\end{array}$ & Substrate & $\begin{array}{l}\text { Sulphate or } \\
\text { sulphite } \\
\text { reduced } \\
(\%)\end{array}$ & $\begin{array}{c}\text { Rate of } \\
\text { reduction, } \\
\text { mg. } S^{2-} \times \\
10^{-12} / \\
\text { organism/hr }\end{array}$ & $\begin{array}{c}\delta^{34} \mathbf{S} \text { of } \mathbf{S}^{2-} \\
(\%)\end{array}$ \\
\hline 1 & $\begin{array}{l}25 \\
25 \\
15\end{array}$ & $\begin{array}{l}\mathrm{SO}_{4}{ }^{2-} \\
\mathrm{SO}_{3}{ }^{2-} \\
\mathrm{SO}_{3}{ }^{2-}\end{array}$ & $\begin{array}{l}3.06 \\
2 \cdot 04 \\
1.56\end{array}$ & $\begin{array}{l}1 \cdot 87 \\
\mathbf{3} \cdot 28 \\
0 \cdot 92\end{array}$ & $\begin{array}{l}-16 \cdot 3 \\
-10 \cdot 0 \\
-10 \cdot 0\end{array}$ \\
\hline 2 & $\begin{array}{c}35 \\
15 \\
35 \\
25 \\
15 \\
5^{*} \\
3^{*} \\
15 *\end{array}$ & $\begin{array}{l}\mathrm{SO}_{4}{ }^{2-} \\
\mathrm{SO}_{4}{ }^{2-} \\
\mathrm{SO}_{3}{ }^{2-} \\
\mathrm{SO}_{3}{ }^{2-} \\
\mathrm{SO}_{3}{ }^{2-} \\
\mathrm{SO}_{3}{ }^{2-} \\
\mathrm{SO}_{3}{ }^{2-} \\
\mathrm{SO}_{3}{ }^{2-}\end{array}$ & $\begin{array}{l}1 \cdot 43 \\
1 \cdot 40 \\
2 \cdot 40 \\
2 \cdot 72 \\
3 \cdot 38 \\
1 \cdot 40 \\
1 \cdot 67 \\
5 \cdot 60\end{array}$ & $\begin{array}{r}12 \cdot 30 \\
2 \cdot 42 \\
14 \cdot 30 \\
6 \cdot 45 \\
3 \cdot 58 \\
0 \cdot 50 \\
10 \cdot 50 \\
6 \cdot 76\end{array}$ & $\begin{array}{r}-15 \cdot 5 \\
-16 \cdot 6 \\
-9 \cdot 4 \\
-9 \cdot 4 \\
-7 \cdot 9 \\
-14.3 \\
-1 \cdot 9 \\
+0.3\end{array}$ \\
\hline
\end{tabular}

* Temperature raised to $35^{\circ}$ after $18.5 \mathrm{hr}$ at $5^{\circ}$ and then lowered to $15^{\circ}$ after $1 \mathrm{hr}$ at $35^{\circ}$. The sulphide formed in each interval was analysed separately.

The experiment at $5^{\circ}$ (Table 2) required $18 \cdot 5 \mathrm{hr}$ incubation to collect enough sulphide for isotope analysis. The temperature of the reaction mixture was then rapidly raised to and held at $35^{\circ}$ for $1 \mathrm{hr}$ and then lowered to and held at $15^{\circ}$ for $5 \mathrm{hr}$. The sulphides produced during the three intervals were collected separately and analysed. With the rise in temperature, fractionation dropped markedly from $\delta^{34} \mathrm{~S}-14 \cdot 3 \%$ to $\delta^{34} \mathrm{~S}-1.9 \%$, and was completely suppressed by the second lowering (Table 2). As in the low-temperature experiments with sulphate, the normal mechanisms controlling fractionation were disrupted by the environmental changes imposed.

\section{Sulphite reduction by resting Saccharomyces cerevisiae}

Attempts to demonstrate sulphate reduction by $S$. cerevisiae suspensions were unsuccessful although cell-free extracts catalyse the process (Wilson \& Bandurski, 1958). Sulphite reduction, however, was obtained with glucose as the electron donor. The rate of reduction was difficult to determine accurately since it was inconsistent and diminished with time, possibly because of toxicity of either the sulphite or sulphide. It was, however, slower than sulphite reduction by Desulfovibrio 
desulfuricans at the same temperature by approximately one order of magnitude. Six separate experiments yielded an average rate of $0.93 \times 10^{-12} \mathrm{mg} . \mathrm{S}^{2-} /$ organism/ $\mathrm{hr}$. Temperature did not appear to have a great effect on the rate over the range $22-38^{\circ}$ (Table 3), possibly because of opposing effects on rate of reduction and toxicity.

The isotope effect was very large, varying from $34 \%$ to a maximum enrichment of $41 \%$ (Table 3 ). Although the data suggest increasing fractionation with increasing rate of reduction, this cannot be given much significance since the ranges for both parameters were small and the rate measurements were approximations. It is apparent, however, that much greater fractionations are obtained during sulphite reduction by yeast than by Desulfovibrio desulfuricans even at comparable rates of reduction.

Table 3. Isotopic fractionation during sulphite reduction by resting suspensions of Saccharomyces cerevisiae

Glucose as electron donor. $\delta^{34} \mathrm{~S}$ measured relative to ${ }^{34} \mathrm{~S} /{ }^{32} \mathrm{~S}$ of starting sulphite.

\begin{tabular}{|c|c|c|c|c|c|}
\hline $\begin{array}{c}\text { Expt. } \\
\text { no. }\end{array}$ & $\underset{\left({ }^{\circ}\right)}{\text { Temp. }}$ & $\begin{array}{l}\text { Sulphite } \\
\text { (M) }\end{array}$ & $\begin{array}{c}\text { Sulphite } \\
\text { reduced } \\
(\%)\end{array}$ & $\begin{array}{c}\text { Rate of } \\
\text { reduction, } \\
\text { mg. } S^{2-} \times \\
10^{-12} / \\
\text { organism/ } \\
\text { hr }\end{array}$ & $\begin{array}{c}\delta^{34} \mathbf{S} \text { of } \mathbf{S}^{2-} \\
(\% \circ)\end{array}$ \\
\hline 1 & 30 & $0 \cdot 03$ & 0.50 & $0 \cdot 63$ & $-37 \cdot 1$ \\
\hline 2 & $\begin{array}{l}\mathbf{3 0} \\
\mathbf{3 0}\end{array}$ & $\begin{array}{l}0 \cdot 02 \\
0 \cdot 06\end{array}$ & $\begin{array}{l}0.09 \\
0.08\end{array}$ & $\begin{array}{l}0.81 \\
0.57\end{array}$ & $\begin{array}{l}-36 \cdot 0 \\
-34 \cdot 0\end{array}$ \\
\hline 3 & $\begin{array}{l}22 \\
30 \\
38\end{array}$ & $\begin{array}{l}0 \cdot 02 \\
0 \cdot 02 \\
0 \cdot 02\end{array}$ & $\begin{array}{l}0 \cdot 11 \\
0 \cdot 11 \\
0 \cdot 08\end{array}$ & $\begin{array}{l}1.06 \\
1.47 \\
1.03\end{array}$ & $\begin{array}{l}-36 \cdot 1 \\
-41 \cdot 0 \\
-39 \cdot 4\end{array}$ \\
\hline
\end{tabular}

Fractionation during assimilation of sulphate

A heterotrophic bacterium, Escherichia coli, a green alga, Ankistrodesmus sp., and a yeast, Saccharomyces cerevisiae, were grown with sulphate as the sole sulphur source, and the isotopic ratios of the assimilated sulphur determined. Only a very small fractionation was observed, but it was always in the same direction, i.e., an enrichment of ${ }^{32} \mathrm{~S}$ in the assimilated sulphur (Table 4).

Table 4. Isotopic fractionation during incorporation of sulphate sulphur into organic sulphur during growth

Growth conditions and media given in text. $\delta^{34} \mathrm{~S}$ measured relative to ${ }^{34} \mathrm{~S} /{ }^{32} \mathrm{~S}$ of starting sulphate.

\begin{tabular}{lcc}
\multirow{4}{*}{$\begin{array}{c}\text { Organism } \\
\text { Escherichia coli }\end{array}$} & $\begin{array}{c}\text { \% dry weight } \\
\text { organisms }\end{array}$ & $\begin{array}{c}\delta^{34} \mathrm{~S} \\
(\%)\end{array}$ \\
Ankistrodesmus sp. & $0 \cdot 62$ & $-2 \cdot 2$ \\
& $0 \cdot 60$ & $-2 \cdot 8$ \\
Saccharomyces cerevisiae & $0 \cdot 46$ & -0.9 \\
& $0 \cdot 46$ & $-1 \cdot 8$ \\
& $0 \cdot 30$ & $-2 \cdot 8$
\end{tabular}


Fractionation during mineralization of organic sulphur

The cleavage of the sulphydryl group of cysteine by Proteus vulgaris (Tarr, 1933, 1934) resulted in an enrichment of the lighter isotope in the hydrogen sulphide with a maximum $\delta^{34} \mathrm{~S}-5 \cdot 1 \%$ (Table 5).

Table 5. Isotopic fractionation during the liberation of hydrogen sulphide from cysteine by resting suspensions of Proteus vulgaris

A solution of $350 \mathrm{mg}$. cysteine hydrochloride per $100 \mathrm{ml}$. of phosphate buffer, pH 7.2, and a cell density of 475 Klett-Summerson units (No. 54 filter) used. $\delta^{34}$ measured relative to ${ }^{34} \mathrm{~S} /{ }^{32} \mathrm{~S}$ of cysteine sulphur.

\begin{tabular}{|c|c|c|c|}
\hline $\begin{array}{c}\text { Temp. } \\
\left({ }^{\circ}\right)\end{array}$ & $\begin{array}{c}\text { Sulphide } \\
\text { formed } \\
(\%)\end{array}$ & $\begin{array}{c}\text { Rate of } \mathrm{S}^{2-} \\
\text { release, } \\
\mathrm{mg} \cdot \times \mathbf{1 0}^{-3} / \\
\mathrm{ml} \cdot / \mathrm{hr}\end{array}$ & $\begin{array}{c}\delta^{34} \mathbf{S} \text { of } \mathbf{S}^{2-} \\
(\%)\end{array}$ \\
\hline 40 & 1.9 & $3 \cdot 2$ & $-5 \cdot 1$ \\
\hline 25 & $4 \cdot 7$ & 1.8 & $-4 \cdot 3$ \\
\hline
\end{tabular}

Chemosynthetic oxidation of sulphide by Thiobacillus concretivorus

The studies on hydrogen sulphide oxidation yielded results (Table 6) similar to those of Kaplan \& Rafter (1958). Both the sulphur and sulphate formed as products during the oxidation were enriched in ${ }^{32} \mathrm{~S}$ relative to the starting sulphide. The sulphur was only slightly enriched, the maximum measured being about $2 \cdot 5 \%$. The sulphate, however, showed a greater enrichment. Neither sulphur nor sulphate was formed in the uninoculated controls, showing that the oxidation was biological.

Table 6. Isotopic fractionation during the oxidation of sulphide by growing cultures of Thiobacillus concretivorus and Chromatium sp.

Culture conditions given in text. $\delta^{34} \mathrm{~S}$ measured relative to the ${ }^{34} \mathrm{~S} /{ }^{32} \mathrm{~S}$ of the starting sulphide.

\begin{tabular}{|c|c|c|c|c|c|c|}
\hline \multirow{2}{*}{$\begin{array}{l}\text { Expt. } \\
\text { and } \\
\text { organism }\end{array}$} & \multirow{2}{*}{$\begin{array}{c}\text { Sulphide } \\
\text { oxidized } \\
(\%)\end{array}$} & \multirow{2}{*}{$\frac{\mathrm{SO}_{4}{ }^{2-}-\mathrm{S}}{\mathrm{S}_{x} \mathrm{O}_{6}{ }^{2-}-\mathrm{S}}$} & \multirow{2}{*}{$\frac{S^{\circ}}{\mathrm{S}_{x} \mathrm{O}_{6}{ }^{2-}-\mathrm{S}}$} & \multicolumn{3}{|c|}{$\delta^{84} \mathrm{~S}(\%)$} \\
\hline & & & & $\mathrm{SO}_{4}{ }^{2-}$ & $\mathbf{S}^{\circ}$ & $\mathrm{S}_{x} \mathrm{O}_{6}^{2-}$ \\
\hline \multicolumn{7}{|c|}{ T. concretivorus } \\
\hline $1 a$ & - & - & 一 & $-11 \cdot 2$ & $\mathbf{0}$ & 一 \\
\hline $\boldsymbol{b}$ & - & - & - & $-10 \cdot 5$ & $-1 \cdot 0$ & - \\
\hline$c$ & - & - & - & $-11 \cdot 1$ & -0.7 & - \\
\hline 1* & - & $4 \cdot 8$ & $20 \cdot 3$ & - & - & $+3 \cdot 2$ \\
\hline $2 a$ & - & - & - & $-18 \cdot 0$ & $-2 \cdot 5$ & - \\
\hline $\boldsymbol{b}$ & - & - & - & $-15 \cdot 6$ & $-1 \cdot 2$ & - \\
\hline$c$ & 一 & - & - & $-16 \cdot 3$ & $-1 \cdot 4$ & - \\
\hline$d$ & - & - & - & -16.7 & $-2 \cdot 3$ & - \\
\hline 2* & - & $2 \cdot 9$ & $35 \cdot 6$ & - & - & $+0 \cdot 6$ \\
\hline $\mathbf{3} a$ & - & $1 \cdot 1$ & $44 \cdot 6$ & $-10 \cdot 6$ & $+1 \cdot 2$ & $+19 \cdot 0$ \\
\hline$b$ & - & 1.5 & $75 \cdot 0$ & $-13 \cdot 4$ & -1.2 & $+10 \cdot 6$ \\
\hline$c$ & - & $1 \cdot 2$ & $50 \cdot 0$ & $-13 \cdot 1$ & $-1 \cdot 3$ & +7.5 \\
\hline \multicolumn{7}{|c|}{ Chromatium sp. } \\
\hline $4 a$ & $27 \cdot 0$ & 1.94 & $1 \cdot 35$ & $+0 \cdot 5$ & $-5 \cdot 1$ & $+10 \cdot 5$ \\
\hline$b$ & $46 \cdot 0$ & $2 \cdot 14$ & $2 \cdot 47$ & +0.9 & $-3 \cdot 6$ & $+8 \cdot 4$ \\
\hline$c$ & $22 \cdot 0$ & 1.00 & 0.55 & +0.7 & $-10 \cdot 0$ & $+11 \cdot 2$ \\
\hline$d$ & $17 \cdot 0$ & $1 \cdot 50$ & 0.94 & -2.9 & -8.5 & $+4 \cdot 9$ \\
\hline
\end{tabular}


Previous experiments by Kaplan \& Rafter (1958) indicate that the abiological oxidation of sulphide to sulphur leads to a slight enrichment of ${ }^{34} \mathrm{~S}$ in the product of about $3 \%$. The enrichment of the lighter isotope in the present experiment must therefore be considered significant.

In most experiments, a large enrichment of ${ }^{34} \mathrm{~S}$ was found in a sulphur fraction designated $\mathrm{S}_{a} \mathrm{O}_{6}{ }^{2-}$ (Table 6). The exact composition of this moiety is not known but it is presumed to be a polythionate from the method employed for its determination. Under the conditions of the experiments, $\mathrm{S}_{x} \mathrm{O}_{6}{ }^{2-}$ accumulated in the medium in amounts one-fifth to one times that of sulphate and was absent from uninoculated controls.

\section{Photosynthetic oxidation of sulphide by Chromatium sp.}

Three products, elemental sulphur, polythionate and sulphate, were obtained from the photosynthetic oxidation of sulphide by a Chromatium sp. when growth of cultures was halted at an intermediate stage in substrate oxidation. Elemental sulphur accumulated as intracellular globules while the other two products were in the medium. As with chemosynthetic sulphide oxidation, the polythionate fraction was markedly enriched in ${ }^{34} \mathrm{~S}$ (Table 6). In contrast to the thiobacillus oxidation, however, no significant fractionation was found in sulphate and a marked enrichment of ${ }^{32} \mathrm{~S}$ occurred in elemental sulphur.

\section{Metabolism of elemental sulphur}

Sulphur oxidation by Thiobacillus concretivorus and by Chromatium sp., and reduction by Saccharomyces cerevisiae, did not result in significant fractionation in the products, sulphate and sulphide respectively. The observed $\delta^{34} \mathrm{~S}$ values ranged from $-0 \cdot 1$ to $+1 \cdot 4$ for $T$. concretivorus, $+0 \cdot 3$ to $+0 \cdot 4$ for Chromatium sp., and -0.6 to +0.3 for $S$. cerevisiae. The significance of this lack of isotope discrimination in the oxidation of elemental sulphur to the question of sulphur transport has been discussed elsewhere (Kaplan \& Rittenberg, 1962a).

\section{DISCUSSION}

The data presented here show that discrimination between sulphur isotopes commonly occurs in metabolic function. Significant fractionation was found in all processes examined except those in which elemental sulphur served as a starting substrate. The magnitude of the effect differed in different processes, being greatest during sulphate reduction by Desulfovibrio desulfuricans and sulphite reduction by Saccharomyces cerevisiae. Metabolic reactions represented by identical overall equations did not necessarily yield the same isotope effect, e.g. sulphite reduction by $D$. desulfuricans and by $S$. cerevisiae. This finding, in itself, shows that an understanding of the fractionation mechanisms in organisms requires more than a consideration of a single rate-limiting step in the non-enzymic reaction sequence leading from the same initial to final states.

Fractionation during sulphate and sulphite reduction was investigated most completely in this study and it is only for these processes that a significant body of information exists in the literature. Our data show that with lactate and ethanol as electron donors, fractionation decreases with increasing rate of sulphate reduction. Temperature and sulphate or lactate concentration, within the 'physiological' 
range, appear to influence fractionation only in so far as they influence rate of reduction. These findings are in complete agreement with the results of Harrison \& Thode (1958). In contrast, when hydrogen is the electron donor, fractionation increases with increasing rate of reduction. With hydrogen, the rate of sulphate reduction is more rapid than with ethanol or lactate at the same temperature.

An attempt was made by Harrison \& Thode (1958) to explain the mechanism controlling fractionation during sulphate and sulphite reduction by postulating only two rate-controlling steps; the entrance of sulphate into the cell and the breaking of the sulphur-oxygen bond during reduction of sulphate to sulphite. The former was assumed to have a very small isotope effect and to regulate fractionation at very high rates of sulphate reduction or at very low sulphate concentrations. The latter was believed to have a kinetic isotope effect similar to that for the chemical reduction of sulphate, $22 \%$ (Harrison \& Thode, 1957), and to be important at low rates of sulphate reduction.

This explanation is not adequate to explain the data now available. Fractionations much greater than $22 \%$ occur, and there is no reason to believe that the highest observed laboratory value, $46 \%$, is a maximum since enrichments of $62 \%$ have been observed in nature under conditions where recycling of sulphur is unlikely (Kaplan et al. 1963). Thus the breaking of the $\mathrm{S}-\mathrm{O}$ bond in sulphite formation from sulphate cannot be the dominant process controlling fractionation at low rates of sulphate reduction.

That sulphate entrance into the cell is the rate- (and fractionation-) controlling step at high rates of sulphate reduction is equally unlikely. Since, with all other conditions the same, the rate of reduction is always much greater with hydrogen than with lactate or ethanol, then the availability of electrons at the reduction site and not penetration of sulphate must be the limiting factor for the organic donors mentioned. What is rate-limiting with hydrogen as the donor is unknown. However, with this electron source fractionation increases with increased rate of reduction.

Mass difference allows discrimination between isotopes in both chemical and physical processes. In chemical reactions, the difference in mass of the nuclides results in chemical bonds of different stability and consequently the reaction rates are different for each mass. The fractionation factor depends on the nature of the reaction(s) and will differ for steady state or equilibrium processes as compared to unidirectional ones. Thus, for the unidirectional reduction of sulphate to sulphide, with the step to sulphite rate-limiting, a kinetic isotope effect of 1.010 or 1.035 was calculated, depending on the assumed nature of the activated complex, and an experimental value of 1.021 was observed (Harrison \& Thode, 1957). However, for the equilibrium reaction

$$
{ }^{32} \mathrm{SO}_{4}{ }^{2-}+\mathrm{H}_{2}{ }^{34} \mathrm{~S} \rightleftharpoons{ }^{34} \mathrm{SO}_{4}{ }^{2-}+\mathrm{H}_{2}{ }^{32} \mathrm{~S}
$$

a much greater fractionation was calculated $\left(K=1.085\right.$ at $0^{\circ}$ and 1.074 at $25^{\circ}$; Tudge \& Thode, 1950).

In attempting to interpret the fractionation data in biological sulphate reduction one must decide whether a unidirectional or equilibrium situation exists and this requires a consideration of the mechanism of penetration of sulphate into the cell.

Littlewood \& Postgate (1957) studying gross permeability of resting organisms by the 'thick suspension' technique of Mitchell \& Moyle (1956) and Furusaka (1961) 
measuring uptake of radioactive sulphate concluded that Desulfovibrio desulfuricans is not freely permeable to sulphate. Furusaka showed, however, that sulphate could reach an internal concentration appreciably greater than that of the suspending medium and found that the kinetics of accumulation was influenced by oxygen and selenate. He concluded that a significant accumulation of $\mathrm{SO}_{4}{ }^{2-}$ occurs in the organism and that the transport of sulphate is associated with its reduction. Whether transport is in ionic form remains unanswered. If so, a fractionation could occur during the process of penetration which, following the laws for a unidirectional reaction, would yield a maximum enrichment factor of $\left({ }^{34} \mathrm{SO}_{4}{ }^{16} /{ }^{32} \mathrm{SO}_{4}{ }^{16}\right)^{\frac{1}{2}} 1.010$ or $\delta^{34} \mathrm{~S}-10 \%$. This factor would probably be negligible especially if activation occurred previous to entry.

If there is no equilibrium between external and internal sulphate and all the sulphate that enters is reduced to sulphide then the maximum enrichment would be $10 \%$ in favour of ${ }^{32} \mathrm{~S}$. Since considerably greater fractionations have been observed, it is apparent that for the non-equilibrium assumption to be valid a sink for heavy sulphur would have to exist, perhaps a side reaction draining off ${ }^{34} \mathrm{~S}$ or a residual pool of sulphate within the cells greatly enriched in ${ }^{34} \mathrm{~S}$. As no side reactions have ever been demonstrated during sulphate reduction by Desulfovibrio desulfuricans it is pointless to speculate on this possibility further. The pool alternative is very unlikely, despite the demonstration by Furusaka (1961) that one exists during sulphate reduction, since calculations show that an approximately $2 \mathrm{M}$ sulphate concentration of $\delta^{34} \mathrm{~S}+36 \%$ would be required within the organisms to account for some of the data, and much lower extracellular sulphate levels are inhibitory. This is not to imply that an intracellular sulphate pool does not exist but only that it could not be large enough to account for observed fractionations.

If it is assumed that the intracellular sulphate is in equilibrium with the external sulphate reservoir, as is suggested by the data of Furusaka (1961), then the kinetic fractionation effect across the boundary will be lessened, since the lighter isotope will emerge as well as enter more readily than the heavier one. However, under these conditions one is no longer dealing with strictly a unidirectional process and, to the extent that the enzymic reactions in the multiple steps of sulphate reduction are reversible, the situation becomes a steady-state condition up to the point of the rate-limiting reaction. The resulting fractionation would be the sum of the equilibrium effects plus the kinetic effect of the rate-limiting step.

The detailed intermediary metabolism of sulphate reduction is not yet known. For Desulfovibrio desulfuricans the first two reactions are (Peck, 1962):

$$
\begin{gathered}
\mathrm{ATP}+\mathrm{SO}_{4}{ }^{2-} \stackrel{\mathrm{ATP} \text {-sulfurylase }}{\rightleftharpoons} \mathrm{APS}+\mathrm{PP} ; \\
\mathrm{APS}+2 e \stackrel{\text { APS-reductase }}{\rightleftharpoons} \mathrm{AMP}+\mathrm{SO}_{3}{ }^{2-} .
\end{gathered}
$$

The equilibrium for $(1)$ is far to the left $\left(K \sim 10^{-8}\right.$, Robbins \& Lipmann, 1958) and, in cell-free systems, at least, pyrophosphatase is needed to pull the reaction. The equilibrium constant for reaction (2) has not yet been determined, although the reaction is reversible (Peck, 1961). The reduction of sulphite has not been thoroughly investigated but it is known that cytochrome $c_{3}$ functions here (Postgate, 1956) as well as in sulphate reduction (Peck, 1959). The extent to which the reactions in sulphite reduction are reversible is completely unknown, although a tenuous 
argument for reversibility is that organisms oxidizing reduced sulphur compounds as energy sources do so via APS (Peck, 1960).

Assuming the reversibility of the entire sequence then an active exchange between $\mathrm{SO}_{4}{ }^{2-}$ and $\mathrm{H}_{2} \mathrm{~S}$ could occur, and a fractionation factor of 1.074 might be approached. In actuality, however, sulphate reduction must be considered unidirectional beyond the rate-limiting step. The further along in the reaction sequence this step occurs and the slower it is relative to the preceding steps the greater the expected fractionation. Since this step and/or its relative rate could differ under different physiological or environmental conditions, the physiological functioning of the organism must be of great significance in the fractionation process. The existence of strain differences, as was found, would thus be expected. Further, any imposed condition which disrupts the normal functioning of the organism should have a marked influence on fractionation. The anomalous results at $0^{\circ}$ and the suppression of isotope discrimination in the temperature variation experiments during sulphite reduction are cases in point. In the former instance, the temperature was well below the normal growth range; in the latter, the abrupt changes of temperature might well have caused cell damage.

As has already been pointed out, the transfer of electrons from lactate and ethanol must have been rate-limiting in most experiments with these donors and thus reaction (2) or a similar reductive step further in the sequence would control the flow of sulphur through the cell. The faster the rate-limiting step, the smaller the steady state pool of preceding intermediates and the smaller the equilibrium effect on fractionation. This would account for the inverse relation between rate of reduction and fractionation observed with these donors. Since the isotope effect was smaller with hydrogen as compared to the organic donors and increases with rate of reduction, it might be assumed that reaction (1) is rate-limiting.

Furusaka (1961) has shown that at $37^{\circ}$ the rate of sulphate entry into the cell is somewhat greater than the rate of reduction of sulphate by hydrogen whereas at $0^{\circ}$ reduction is much more rapid than transport. Thus with decreasing temperature, control of fractionation would shift from some intracellular process to the permeation step. The small fractionations in the low-temperature experiments of the present study and those at very low sulphate concentrations observed by Harrison \& Thode (1958) could be explained in this manner.

Because of the limited data available, little can be said about the factors controlling fractionation in the other processes investigated. Except for a single experiment in which a relatively high fractionation was observed, rate of reduction did not appear to be a factor in sulphite reduction by either Desulfovibrio desulfuricans or Saccharomyces cerevisiae. The rate of reduction, however, was much lower with the latter organism and the isotopic effect strikingly higher. It is known that sulphite reduction is linked to $\mathrm{NADPH}_{2}$ in S. cerevisiae (Wainwright, 1961) and to cytochrome $c_{3}$ in $D$. desulfuricans (Postgate, 1956) and this difference in mechanism may be the basis of the different fractionation factors. The difference in fractionation during sulphate assimilation and sulphite reduction by $S$. cerevisiae is also marked, and implies a major dissimilarity in either transport or metabolism of the two ions.

Escherichia coli, Saccharomyces cerevisiae and Ankistrodesmus sp. yielded a similar, and very small, enrichment of ${ }^{32} \mathrm{~S}$ in cellular organic sulphur when grown on sulphate as the sole sulphur source. Ishii (1953) in a similar study found no fractionation 
during sulphur assimilation by higher plants. The data suggest that there is no intracellular sulphate pool and that all the sulphate that enters during growth is rapidly assimilated. Fractionation in this event would occur only at the cell boundary and only a small effect would be expected.

A consideration of the isotope distribution data in chemo-synthetic and photosynthetic sulphide oxidation leads to some interesting, and somewhat unorthodox, suggestions with respect to the intermediary metabolism of these processes. In both instances a compound(s) markedly enriched in ${ }^{34} \mathrm{~S}$ and reacting like a polythionate is found in appreciable amounts in the media. In chemosynthetic oxidation, the sulphate formed is correspondingly enriched, but in ${ }^{32} \mathrm{~S}$. Since the heavier isotope accumulates in the polythionate and the lighter in the sulphate it can be argued that the former represents a residual component from which sulphate is directly formed. The elemental sulphur, deposited extracellularly, is only slightly enriched in ${ }^{32} \mathrm{~S}$. Since the oxidation of extracellularly supplied sulphur does not result in any isotope discrimination, the metabolically deposited sulphur cannot be an intermediate in the formation of the light sulphate. The isotope data thus put polythionate in the direct pathway of sulphide oxidation to sulphate and relegate elemental sulphur to a product of a side reaction. The first conclusion at least has been reached by many investigators on the basis of more conventional data (see review by Vishniac \& Santer, 1957).

If one follows the same argument with the data from photosynthetic oxidation, the conclusion with respect to elemental sulphur is the same. Here sulphur and not sulphate is the light component and one would assume it arises from the polythionate. Although this has not previously been proposed for photosynthetic bacteria, it has frequently been suggested for sulphur formation by the thiobacilli (Vishniac \& Santer, 1957). If the path of oxidation of sulphide to sulphate involved the initial formation of elemental sulphur, it would be expected that the fractionation process would lead to an enrichment of ${ }^{32} \mathrm{~S}$ in the sulphate, which would have the same fractionation factor as the sulphur relative to sulphide (if no further enrichment occurred) or a greater one. Thus, the data also seem to exclude elemental sulphur as an intermediate in sulphate formation from sulphide.

We are deeply indebted to Dr T. A. Rafter, Director, Institute of Nuclear Sciences, New Zealand, whose laboratory performed most of the mass spectrometer analyses, and also to Drs H. C. Urey and R. Bowen, University of California, La Jolla, for making their mass spectrometer available to us. We wish to thank Drs J. Postgate, C. Parker and June Lascelles for the cultures of Desulfovibrio desulfuricans, Thiobacillus concretivorus and Chromatium sp. respectively.

This research was supported by a grant from the Petroleum Research Fund administered by the American Chemical Society. Grateful acknowledgement is hereby made to the donors of said fund. 


\section{REFERENCES}

Curtis, O. F. \& Clark, D. G. (1950). Introduction to Plant Physiology. New York: McGraw Hill.

FEeLY, H. W. \& KuLP, J. L. (1957). Origin of Gulf Coast salt-dome sulfur deposits. Bull. Amer. Ass. Petrol. Geol. 41, 1802.

Fursuaka, C. (1961). Sulphate transport and metabolism by Desulphovibrio desulphuricans. Nature, Lond. 192, 427.

Harrison, A. G. \& Thode, H. G. (1957). The kinetic isotope effect in the chemical reduction of sulphate. Trans. Faraday Soc. 53, 1648.

Harrison, A. G. \& Thode, M. G. (1958). Mechanism of the bacterial reduction of sulphate from isotope fractionation studies. Trans. Faraday Soc. 54, 84.

Hulston, J. R. \& Shilton, B. W. (1958). Sulphur isotopic variations in nature. IV. Measurement of sulphur isotopic ratio by mass spectrometer. N.Z. J. Sci. 1, 91.

IsHrr, M. M. (1953). The fractionation of sulphur isotopes in the plant metabolism of sulphates. Thesis, McMaster University, Ontario, Canada.

JENSEN, M. L. (1958). Sulfur isotopes and the origin of sandstone-type uranium deposits. Econ. Geol. 53, 588.

Jones, G. E. \& Starkey, R. L. (1957). Fractionation of stable isotopes of sulfur by micro-organisms and their role in deposition of native sulfur. Appl. Microbiol. 5, 111.

KAPLAN, I. R. (1962). Sulphur isotope fractionations during microbiological transformations in the laboratory and in marine sediments. Dissertation, University of Southern California, Los Angeles, California.

Kaplan, I. R., Emery, K. O. \& Rittenberg, S. C. (1963). The distribution and isotopic abundance of sulphur in recent marine sediments off southern California. Geochim. et cosmoch. Acta, 27, 297.

Kaplan, I. R. \& RAFter, T. A. (1958). Fractionation of stable isotopes of sulfur by thiobacilli. Science, 127, 517.

Kaplan, I. R., Rafter, T. A. \& Hulston, J. R. (1960). Sulphur isotopic variations in nature. VIII. Application to some biogeochemical problems. N.Z. J. Sci. 3, 338.

Kaplan, I. R. \& Rittenberg, S. C. (1962a). Fractionation of isotopes in relation to the problem of elemental sulphur transport by micro-organisms. Nature, Lond. 194, 1098.

KAPLAN, I. R. \& RittenberG, S. C. (1962 b). The microbiological fractionation of sulfur isotopes. In Biogeochemistry of Sulfur Isotopes. Ed. by M. L. Jensen, Department of Geology, Yale University, New Haven, U.S. 80.

LARSEN, H. (1953). On the microbiology and biochemistry of the green sulfur bacteria. K. norske vidensk. Selsk. Skr. $1,1$.

Littlewood, D. \& Postgate, J. R. (1957). On the osmotic behaviour of Desulphovibrio desulphuricans. J. gen. Microbiol. 16, 596.

Mechalas, B. J. \& Rittenberg, S. C. (1960). Energy coupling in Desulfovibrio desulfuricans. J. Bact. 80, 501.

Mrtchell, P. \& Moyle, J. (1956). Osmotic function and structure in bacteria. In Bacterial Anatomy. Symp. Soc. gen. Microbiol. 6, 150.

Parker, C. D. (1947). Species of sulphur bacteria associated with the corrosion of concrete. Nature, Lond. 159, 439.

PECK, H. D. (1959). The ATP-dependent reduction of sulfate with hydrogen in extracts of Desulfovibrio desulfuricans. Proc. nat. Acad. Sci., Wash. 45, 701.

Peck, H. D. (1960). Adenosine 5'-phosphosulfate as an intermediate in the oxidation of thiosulfate by Thiobacillus thioparus. Proc. nat. Acad. Sci., Wash. 46, 1053.

PECK, H. D. (1961). Evidence for the reversibility of adenosine-5'-phosphosulfate reductase. Biochim. biophys. Acta, 49, 621.

PECK, H. D. (1962). Comparative metabolism of inorganic sulfur compounds in microorganisms. Bact. Rev. 26, 67.

Postgate, J. R. (1951). The reduction of sulphur compounds by Desulphovibrio desulphuricans. J. gen. Microbiol. 5, 725. 
Postgate, J. R. (1956). Cytochrome $c_{3}$ and desulphoviridin; pigments of the anaerobe Desulphovibrio desulphuricans. J. gen. Microbiol. 14, 545.

RAFTER, T. A. (1957). Sulphur isotopic variations in nature. I. The preparation of Roulphur dioxide for mass spectrometer examination. N.Z. J. Sci. Tech. 38B, 849. sberts, R. B., Abelson, P. H., Cowie, D. B., Bolton, E. T. \& Britten, R. J. (1955). Studies of biosynthesis in Escherichia coli. Publ. Carneg. Instn, no. 607.

Robbins, P. W. \& Lipmann, F. (1958). Enzymatic synthesis of adenosine-5'-phosphosulfate. J. biol. Chem. $233,686$.

TARR, H. L. A. (1933). The enzymatic formation of hydrogen sulphide by certain heterotrophic bacteria. Biochem. J. 27, 1869.

TARR, H. L. A. (1934). The enzymatic formation of hydrogen sulphide by certain heterotrophic bacteria. Biochem. J. 28, 192.

Thode, H. G., Kueerekoper, H. \& McElcheran, D. E. (1951). Isotope fractionation in the bacterial reduction of sulphate. Research, Lond. 4, 581.

Thode, H. G., Macnamara, J. \& Fleming, W. H. (1953). Sulphur isotope fractionation in nature and the geological biological time scales. Geochim. et cosmoch. Acta, 3, 235.

Thode, H. G., Monster, J. \& Dunford, H. B. (1961). Sulphur isotope geochemistry. Geochim. et cosmoch. Acta, 25, 159.

Thode, H. G., Wanless, R. K. \& Wallouch, R. (1954). The origin of native sulphur deposits from isotope fractionation studies. Geochim. et cosmoch. Acta, 5, 286.

TudGe, A. P. \& Thode, H. G. (1950). Thermodynamic properties of isotopic compounds of sulphur. Can. J. Res., $28 \mathrm{~B}, 567$.

Vishniac, W. \& Santer, M. (1957). The thiobacilli. Bact. Rev. 21, 195.

WarNwright, T. (1961). Sulphite reduction by yeast enzymes. Biochem. J. 80, 27 P.

Wilson, L. G. \& Bandurski, R. S. (1958). Enzymatic reduction of sulfate. J. Am. chem. Soc. 80, 5576 . 